\title{
Challenging Intern Nation: A Roundtable with Intern Labour Activists in Canada
}

\author{
Nicole S. Cohen* and Greig de Peuter** \\ * Nicole S. Cohen, University of Toronto Mississauga, Canada, nicole.cohen@utoronto.ca \\ ** Greig de Peuter, Wilfrid Laurier University, Waterloo, Canada, gdepeuter@wlu.ca
}

\begin{abstract}
Internships have gained critical attention in Canada, thanks largely to the efforts of intern labour activists, who have generated media coverage, lobbied and advised politicians, conducted education and outreach, and advocated for an end to the proliferation of unpaid internships in Canada. This roundtable interview with intern labour activists Ella Henry, Andrew Langille, Joshua Mandryk, and Claire Seaborn was conducted by Nicole Cohen and Greig de Peuter in Toronto on March 1, 2015. Follow up interviewing was conducted over e-mail in May 2015. The interview has been edited and condensed.
\end{abstract}

Keywords: internships, intern activism, labour, youth, media activism

Acknowledgement: We would like to thank William Webb for research assistance and the Social Sciences and Humanities Research Council of Canada for financial support.

Can you tell us about how you became involved in activism around internships? What sparked your interest in the issue?

Andrew Langille (AL): I started a Master's program at Osgoode Hall Law School at York University in 2010. The next year, I needed to write a paper for a course on the individual contract of employment. I asked David Doorey, a professor at York, for some ideas. He had written a blog post on unpaid internships, but no research had been done on the issue. David suggested that I take a crack at writing something. So, I wrote a survey of some of the legal aspects of unpaid internships. I posted about it on my blog and it snowballed from there. More and more people got interested in the issue. I started talking about it on Twitter, and media requests were coming in. Ross Perlin's book, Intern Nation, came out shortly after I wrote that paper. So, the issue was developing. This was after Steven Greenhouse's article in The New York Times came out. ${ }^{1}$ That article sort of kicked everything off-l think it was critical. I didn't have an overwhelming interest in the issue before, but now I do. It's fascinating, because it encapsulates so many contemporary problems that young people face in the labour market and the wider economy.

Claire Seaborn (CS): I finished my first year of law school at the University of Ottawa in June 2012. At the time, I had no interest in employment law. I entered law school on an application that focused on environmental law and I had experience in activism in the environmental sphere, but not in anything workplace-related. I was socializing with friends and realized that the majority of us had done an internship (I was doing my second unpaid internship for school credit at the Ministry of the Attorney General and, prior to law school, I interned at the Canadian Embassy in Washington; that was not for credit and unpaid). As an early law student, I was eager to learn what the laws were. My first thought was that there should be a union for interns. We decided an advocacy group would be better and came up with the idea of the Canadian Intern Association. I looked up the law on interns and Andrew Langille's name came up. So, I e-mailed him: "Hi, I'm a law student. I'm interested in the issue. What's

\footnotetext{
1 Steven Greenhouse (2010) "The Unpaid Intern, Legal or Not," New York Times, April 2. Accessed March 31, 2015. http://www.nytimes.com/2010/04/03/business/03intern.html?_r=0.
} 
the law on interns? I just want to know." There was a sale that day for .ca domains, and I bought internassociation.ca for $\$ 8$ and started fiddling around with WordPress. That summer the Canadian Intern Association started having meetings. Now, our entire executive is made up of people I didn't know prior to the day the idea started. People have joined through social media or after finding out by word-of-mouth about the organization. So that's when I started. Since then, I have focused a lot more on workplace law, and now that's an area in which I hope to practice law.

Joshua Mandryk (JM): My story is a lot like Claire's. In the beginning of law school at the University of Toronto I started to read what Andrew posted online. In my third year of law school, Ella Henry and I thought that the time was right to do some organizing on campus and try to get students involved. The work that Andrew and Claire had already done and the media coverage of internship issues really made the case for it. We started reaching out to students and getting petitions going in fall of 2013. We decided to form a campaign-based organization: Students Against Unpaid Internship Scams. In Ontario, the timing made sense politically; there was a minority government and we knew that the province would announce its budget in the next six months. We thought the time was ripe to see if we could get some action on the issue.

Ella Henry (EH): I was a year behind Josh in law school, and we met through a shared interest in labour and employment law. During my undergraduate degree I was very involved in student and labour activism, first as a students' union president and later as a union organizer. It seemed to me that unpaid internships were becoming increasingly common-and other than Andrew and Claire, I didn't see many people talking about them. Josh and I formed Students Against Unpaid Internship Scams to bring a student voice to the issue. I think the issue of unpaid internships is a great entry point to begin discussing workers' rights with students.

AL: Early on, I was able to generate coverage with a number of media outlets and develop working relationships with some journalists. I was able to call them up and say, "I think you should look at this issue." Now, The Toronto Star and other media outlets devote substantial resources to covering the issue of precarious work and unpaid internships. Some of the people involved in the internship issue were, to a degree, able to mine social connections. Having some social capital to get your ideas out there is critical. There's some privilege behind getting these issues addressed.

Internships have been criticized from a variety of perspectives over the past few years. Right now, what do you see as the most pressing issues around internships in Canada?

CS: The first thing that comes to mind for me is student internships. When I first got involved it was mostly about unpaid internships outside the school context, and whether or not they're illegal, and educating people about that. Now, more employers, interns, and students are aware that unpaid internships are often illegal and know what the laws are. There's going to be growing discussion about when students' internships should be paid versus unpaid, what workplace rights student interns have, and how long an internship should be. These parts of the issue haven't been explored much. Another issue that interests me is the difference between an "intern" and a "volunteer" or an "employee" and "volunteer."

JM: The volunteer issue is, I think, the next big issue. If you look at the way people are characterizing intern positions outside of post-secondary programs, it's as "volunteer" positions. The law here is ripe to be updated. In terms of internships outside of post-secondary programs, the big issues are onus and enforcement. We talk a lot about enforcement of the laws that are on the books, but the other key idea is onus: employers should not be permitted to self-enforce and accurately apply the law themselves; instead, the onus should be on an employer to get approval for an unpaid internship before they do it. 
EH: I agree with Claire and Josh: student internships and volunteer misclassification are going to be big issues. And in a way, that's a good thing. It means unpaid internships are becoming unpopular and employers don't want to be associated with them. Employers are turning to legal unpaid internships (i.e., student internships) and are naming unpaid positions as volunteer rather than as intern positions. There has been a dramatic shift in public opinion, but we need to continue to be vigilant so we don't see the same problem by another name. The academic internship exception is something I'm particularly concerned about. Post-secondary institutions have shown that they are unwilling or unable to exercise any meaningful oversight or ensure these internships are integrated into an academic program and have pedagogical value. I think we need both law reform and external oversight of academic internships by the Ministry of Labour.

AL: Law reform is an absolute necessity. Ontario has made some reforms around occupational health and safety. There's a need for a standard across Canada. Other issues are the lack of funding for paid positions and the role of government in this respect. In the '90s, the federal government funded thousands of paid internships. I think there's a role for the federal and provincial governments in managing the school-to-labour-market transition. We have to look at deeper policy questions related to labour markets and actually intervene in the economy to help young people. The wider questions that unpaid internships raise are about intergenerational equity. Why have we made this choice that unpaid positions are acceptable? There hasn't been adequate enforcement from government. We see a great deal of ambivalence. If employers are exploiting people and there's no government response and the law is lenient, that's greatly concerning.

CS: Along with the student issue are professional programs. I speak to nurses, nutritionists, and articling law students: all of them are in versions of internships. How these professions choose to train the people that enter them will continue to be an issue. How many months is a professional internship? What is the combination of schooling and training? Is it paid or unpaid?

EH: I think there has been a shift from academic internships that are legitimately integrated into a curriculum and that don't displace paid employees to internships that are indistinguishable from summer jobs or co-op positions students might have. Post-secondary education institutions are underfunded and facing pressure to provide more practical training opportunities, and so they often leap at the chance to provide credit for unpaid internships (and often continue to collect tuition fees).

AL: Underlying a lot of this discussion is a conception of equality and how equality is treated vis-à-vis economic rights. Economic rights are a thorny issue in a market-based economy. And this issue is highlighting contradictions under capitalism. There is ongoing tension between the rights of citizens and employers.

There has been a surprising amount of media coverage of internship issues over the past few years. Do you think that there's a sense that the "battle has been won"? That there's an assumption that, well, "you can't have unpaid internships anymore, so why even talk about it?"

JM: There has been a lot of positive media coverage. I think we're winning the war of ideas on the issue, but we need to be honest that little has been accomplished. In Ontario, there was a short-term enforcement blitz. A few private member's bills, which will not pass, have been presented. There have been some incremental steps in the right direction, but the idea that it's "won" or that there's been any meaningful solution to the problems is untrue. The media coverage and the government's short-term blitz do not change the fact that the current complaints-based system doesn't work. 
CS: I don't think the battle's even gotten started. I'm only beginning to understand the breadth of issues that apply to interns, including human rights issues like discrimination and sexual harassment. And, in the student context, schools should be doing much more. The other issue is that a lot of employers are posting internships without specifying whether they're paid or unpaid, and only notifying interns in an interview. It's difficult for us to shame these companies when we don't have any documents, when they haven't posted anything online to evidence that.

EH: We shouldn't underestimate the impact of the media attention and the corresponding shift in public opinion. Even two years ago, when I talked to people my parents' age about unpaid internships almost everyone thought young people today were just unwilling to work hard and that unpaid internships were a good way to get your foot in the door in a tough economy. Now the majority of those people say that unpaid internships are wrong. I think it's fair to say we've won the first round, but the fight is far from over.

All of you are involved in organizations that advocate around internship issues. Can you describe the activities of the group that you are involved with?

JM: I was involved in Students Against Unpaid Internship Scams. We started in the fall of 2013. We were a campaign-based group. We didn't see ourselves as a permanent group, but, as I said earlier, we thought the time was right to start a campaign. We did petitioning and we had a website that we made ourselves - the website had a form that allowed you to send a message to all the political party leaders, the Minister of Labour, and labour critics. It was a formal letter calling for the demands outlined in our petition. ${ }^{2}$ We demonstrated outside the minister's pre-budget consultation in 2013, chatted with folks of different parties, and did advocacy work: media-relations, writing, and putting forward position papers. Now, I'm an articling student. As a lawyer, I plan to do test cases and continue to push this issue.

The Students' Law Society at the University of Toronto ran a OneDayofPay campaign. It got a lot of coverage. The Faculty of Law at University of Toronto, the student Law Society, and the administration had a proposal-well-intentioned, but, in our opinion, off the mark-to address the prevalence of unpaid positions in the Faculty of Law. They asked students who got a paying summer job to donate a day of their pay in order to pay for their classmates' unpaid placements. Obviously, there are many problems with this, one of which is that a lot of these positions could be illegal, and the role of the legal education institutions should be to challenge these things... The institutions themselves shouldn't be posting these sorts of positions. Who should pay the burden of underfunding? Should it be students who pay $\$ 30,000$ per year in tuition? Or should it be the government?

CS: The Canadian Intern Association advocates against the exploitation of interns. Our mission is to improve internship experiences for interns and employers through law reform, enforcement, cultural change, and awareness. The Canadian Intern Association was founded in June of 2012. One year later, it became a federally incorporated not-for-profit organization. Now, we have seven members on our executive team who are based in Ottawa and Toronto: event planners, public policy majors, people with backgrounds in the arts, in finance... The association is made up of people in their early-twenties who are interested in the issue. All our executive members have done an internship at one point, some paid, some unpaid.

We meet every two months in person, but communicate almost daily online through email, Facebook, and Twitter. We have a website that has a "Wall of Shame" and a "Wall of Fame," which have been really successful. Now, just threatening to a company that we'll put them on our Wall of Shame is enough to make them change their behaviour, or at least have a phone conversation about it.

\footnotetext{
${ }^{2}$ The letter is available at http://fs25.formsite.com/stopunpaidinternshipscams/form1/index.html.
} 
The thing that I do most with the Intern Association is law reform and lobbying. I've enjoyed talking to politicians, building understanding of the law, communicating our policy proposals, and doing media interviews. We've partnered with academics to promote research, and we also give talks at colleges and universities to educate interns and students about their workplace rights. We've done all of this with little to no money.

Andrew [Langille] is counsel to the Canadian Intern Association. He's our go-to lawyer. Interns e-mail us all the time with long descriptions of their experiences, and it's helpful to have someone who is able to discuss their specific issues with them, refer them, and sometimes take on their cases. Essentially, he's giving free legal advice.

\section{Andrew, could you give us a sense of that consultation process?}

AL: Generally, if I get a question, l'll talk to the person on the phone and tell them what to do. Often, it's a matter of directing people to the Ministry of Labour to file a complaint. Typically, they're asking if the internship is legal. Most of the time it's not legal if they're not students. I've dealt with some bad situations, where student interns are working in unsafe environments. You come across instances of sexual harassment and you do your best to direct them to the appropriate resources and give them some advice. But we can't take on every case. We're not set up to do casework.

CS: Although that would be great... One thing that we started early on was a Claim Back Your Pay campaign. We got the idea from a UK campaign. ${ }^{3}$ We posted information on our website about how interns can file a claim with the Ministry of Labour to seek retroactive minimum wage for the hours they've worked. Kyle, one of the executives of the Intern Association, successfully claimed back pay in 2011-he got his money from the employer. Now, he's a great spokesperson for the Claim Back Your Pay campaign, encouraging other interns to do the same thing he did.

There's a coalition of intern groups, called the International Coalition for Fair Internships (fairinternships.org). Can you describe this coalition and speak about your involvement in it?

AL: There is an international coalition of groups that has met over the past few years over Skype to discuss issues related to internships. It's not all that active at the moment, but it exists, and there's communication between groups. It highlights that this is an international issue: the problems that we're facing in Canada are common in other parts of the world, too.

CS: When one of the members of Interns Australia was in Canada, she came to one of our meetings. That's been a great connection. I met Intern Aware when I was in London. It is the only intern association that has enough funding to support a staff member. It was great to see their office, which is a space in a labour union's headquarters (BECTU). I also met people from the Geneva Intern Association. There are so many interns that come and go from Geneva. While Intern Aware does a lot of lobbying, the Geneva Intern Association is very social-they run monthly socials-and it's a helpful resource for interns to find housing in Geneva. l've spoken with Génération Précaire, the French intern organization in Paris, and I've also Skyped with Mikey Franklin in Washington, DC, who runs the American Fair Pay Campaign. There's the group in New York as well, Intern Labor Rights. Andrew's attended the international coalition meetings, and I try to connect with other groups. It's cool seeing what everyone's doing and watching everyone's group evolve. We share ideas and learn about what is working in other jurisdictions. If I was going to summarize the areas where each group has had the most success, I would say: Intern Aware works most closely with unions, Interns Australia works well with the business community, Canadian Intern Association has been the best at engaging politicians, Intern Labor Rights and other US groups have

\footnotetext{
${ }^{3}$ The Claim Back Your Pay campaign in the UK was run by Intern Aware: www.internaware.org/claim-back-yourpay/.
} 
had success with class action lawsuits, Génération Précaire does more demonstrations and protests, and the Geneva Intern Association has a successful petition for the United Nations.

Interns are, as you know first hand, difficult to reach for a variety of reasons, and hard to organize in the traditional sense of organizing: they're dispersed, in short-term positions, and understandably concerned about their reputations and references. But you've had success despite these challenges. In your experience, what organizing strategies have been particularly effective?

JM: I would say we're not really "organizing" interns. We can mobilize people, but I don't think we've figured out a way to organize them in any meaningful sense. People are afraid to file complaints, and people are not taking collective action. It's not as if trade unions are trying to organize interns as employees, yet, if a place has two interns, they're really employees, you could organize them. That isn't happening.

I think we need to say that we haven't really been organizing people. We can mobilize them to sign petitions and sometimes speak out in the media, but most of the times, people are not able to speak out. When I would do advocacy work on campus, people would tell me their story, but they didn't feel comfortable speaking to the media and didn't really want you to talk about their story, and, if you did, it had to be anonymized. There aren't meaningful protections for interns, and organizations like the Intern Association don't have the resources to provide legal services for all of these people, and, even when you do, things like the potential for reputational damage, you can't really do anything about that. So, it's tricky.

CS: I encourage interns to speak to the media, anonymously or not, about their story, and to speak to their employers about their rights. I can't keep track of all the stories I've heard, whether by the e-mails we receive at the Intern Association or just at social gatherings. People know that l'm interested in this issue, so, socially, someone my age or a little younger will say, "Oh, let me tell you about my intern issue." I feel like l've gained this body of knowledge about the situation, but I don't have data or a chart that tracks it: the sexual assaults that l've heard about, the dangerous work environments, or just the exploitative situations that people find themselves in... the injustices.

But I agree that we don't organize people the way a union would. We don't want to collect dues, we don't want to have mandatory meetings, and we don't want to have a formal membership scheme necessarily. We're looking at having at least a newsletter and a mailing list, so that we can contact people, that's really where we're at in terms of trying to actually keep track of individuals. Honestly, l've been struggling with how to keep in touch with such a large group of people. It's overwhelming. There are so many people that we could be helping, but we just don't have the resources.

EH: I agree that we haven't really been organizing people on an ongoing basis. One of the reasons is that interns are afraid of the consequences of speaking out. But I think beyond that there are more reasons interns and students are difficult to organize. High student debt means that many interns are working full time on top of an internship and many students are working multiple part-time or full-time jobs on top of school. One of the ways we've tried to get around these challenges is by using things like petitions, which allow us to show that our campaigns have broad support without requiring a large time commitment from students.

AL: Education is really important in terms of organizing people. There isn't enough education at the post-secondary level in terms of what labour rights people have. That's critical, but it doesn't really get taught.

JM: At the firm where I work, articling students go to high schools and speak to co-op students before they go to their placements, which is a lot of fun. We visit one high school each month maybe, so the majority of students aren't getting this. We cram a lot of labour and employment law in a two-hour session for these high school students. It's a lot of infor- 
mation at once. It's interesting to talk to them, hear their stories, ask what their positions are like, and ask them questions about labour unions. If any of them know anyone in a union, and inevitably it's, like, one or two kids who put their hands up, and one of them, their parent is a construction worker, and the other one, their parent is a public servant of some sort. Otherwise, no one else...

EH: Students Against Unpaid Internship Scams has also done workshops for college and university students, sometimes in partnership with the Communication Workers of AmericaCanada's associate membership program for young workers and students in the media industry.

CS: Something that has been really fun in terms of organizing is the purely online stuff. For example, when the unpaid internship, zero-dollar contracts at Hootsuite, the Vancouverbased company, were posted on Reddit, there was this huge outcry. Hootsuite, being a social media company, freaked. I loved reading the Reddit comments-there was obviously a significant consensus among people who weren't lawyers, weren't involved in the issue whatsoever, about how problematic this was. Within about 30 hours of posting the contracts on our Wall of Shame, I got an e-mail from the CEO of Hootsuite saying, "We're going to fix this. We can see that this is a problem." On our Wall of Shame post, we shared the contracts, some threads from the Reddit community, and basically shamed their practices. They're the best success story, because not only do they pay their interns now, but they retroactively paid their interns the six months prior. That was a great example of organizing that happened 100 percent online. I never even had a phone call with the guy from Hootsuite. It was just posted on our website, then e-mail, then it was fixed, then it was in social media and mainstream media reported that now Hootsuite is paying its interns.

How you would describe the significance of social media to intern activism? What socialmedia tactics do you use, and to what effect? In particular, is "naming-and-shaming" effective?

AL: I think naming-and-shaming is highly effective. Look at one of the biggest offenders, Bell, a major Canadian telecommunications company. Bell Mobility's Professional Management Program - which was a massive unpaid internship program at one of Canada's largest corporations-brought in young workers and asked them to work for free for months at a time. There was sustained critical media coverage of this program, including in the CBC, the Canadian Press, and The Toronto Star, which highlighted the absurdity of a hugely profitable corporation asking young workers for work for free for months on end. There was also a naming-and-shaming element involved, both on social media and on Internet forums like Reddit, where former interns in the Professional Management Program could share their experiences. Bell ended the program in summer 2014 after multiple lawsuits were launched by former interns. I think that's a big success story. So, yes, I think naming-and-shaming can work. For it to be effective, though, there has to be reputational damage that can come to the company. For a smaller employer, I don't think it's useful, but, for the larger players, it can be highly useful.

JM: I think social media is incredibly useful for connecting with people, given the nature of the work: there's not a permanent, large workplace where there's lots of unpaid interns. Interns are a very dispersed population, but they're also, generally speaking, a young and online population. So, social media is useful for connecting with interns. Social media also gives these folks a voice to share their stories: they can't speak up at work, but many will speak up online about their experiences.

CS: Many people on the Intern Association executive first found the organization through social media, usually Twitter or Facebook. Many of them had an idea of starting a similar organization and, in the process of doing that, came across the Intern Association. 
In terms of naming-and-shaming, within the first six months of the Intern Association being formed, there was an idea to start a Wall of Shame and Wall of Fame-but we didn't really know how to do it at first. I was just becoming familiar with the law at that time. We put up a posting about a company based on an e-mail that we received from an intern about a terrible experience at that company. Not only did we post the company's advertisement for the internship, but we also recounted what the intern said about the internship and how problematic it was. Soon after, I got an angry letter threatening to sue for defamation. I sent it to Andrew right away. We talked about it and decided to take that Wall of Shame posting down. Thereafter, we didn't post details about interns' stories and instead just posted the advertisements and what the law was, so that it was not as high risk for defamation. Myself, the organization, and the other executive team people, we don't want to have our names on the website if there's risk of that kind. It's not a Rate My Professor kind of thing, but it'd be cool if there were something like that for internships. We've been able to accomplish largely the same thing just through posting the advertisements.

AL: One other point on social media: Twitter allows for direct access to politicians. I think that's very important because you can tag certain politicians and they do read it.

CS: Politicians also like to re-tweet stuff when they're mentioned. So, when I'm working with a politician on something, they like it when I say, "Thanks so much for the great meeting," "for inviting me to be a witness at this event," or "for creating this great private member's bill." They re-tweet that and it does a lot for them. Lobbying is supposed to be a reciprocal relationship. I can mention them on Twitter. What they're doing for me is helping me advance the issue.

AL: The Ministry of Labour once used its Twitter account to say that they did not like my naming and shaming. They told people to go to the Law Society and file professional standards complaints against me. I called the Ministry of Labour and said that I was going to sue. I had to send a letter to the Ministry of Labour outlining what my Charter of Rights are as a citizen, saying that I can engage in political action. The tweets were removed. I had the ability to fight back, but somebody who doesn't have access to legal counsel... you can see how it would be scary.

We are interested in the kinds of collaborations, associations, and affiliations you've had with different levels, players, and contexts-for example, trade unions, student unions, and politicians, both provincial and federal. Can you describe some of your collaborations? Why are they necessary? Are there any challenges or frustrations that you encounter in these institutional interactions?

AL: There's any number of challenges in interacting with institutional bodies or more established political groups. A lot of these organizations haven't come up with solutions to the rise of precarious work. And, in terms of unpaid internships, there's a steep learning curve. Young people have not been terribly active, in the space of my lifetime, in advocating for their rights in the workplace. Activism does go on, but the issue of unpaid internships is a new issue and people are grappling with how to address it.

Unpaid internships are a controversial issue. It brings up uncomfortable realities about what's happening in the labour market and economy. Certainly, the provincial and federal governments don't want to have serious discussions on this issue. Civil servants who oversee labour regulation don't want to discuss it. They don't know what to do. There are deep, underlying problems related to internships and the school-to-labour-market transition that don't have easy solutions. It takes a long time to get up to speed on the issue, too. It's not easy to understand all the issues, because you have to have an understanding of any number of areas to have a complete picture. Even I don't claim to have a complete understanding of the issue... 
JM: There are some great examples of cooperation with students' unions, trade unions, and politicians. Sometimes, I'm frustrated at the speed at which they've taken up the issue. On the other hand, we've found tremendous support. The University of Toronto Student Union, for example, is very supportive of our campaign. A number of politicians we've worked with have put forward private member's bills on the issue: Andrew Cash, Laurin Liu, Peggy Sattler, and Jonah Schein.

If I were a student union leader, a trade union leader, or a provincial politician, I would see this as a great issue to own and to allow you to speak to your members, your potential members, and your potential supporters. Some folks have been slow to appreciate that. But I think that we've had great collaboration with student unions, trade unions, and politicians. It continues to strengthen, though there's a lot of room to grow.

CS: I'll speak to federal politicians. In the summer of 2013, Justin Trudeau, the leader of the Liberal Party, invited me to a roundtable on youth employment. That happened because I had spoken to an MP, Scott Bryson, a few times while I was at the University of Ottawa about the issue. The roundtable was the first time that I spoke to different stakeholders that I wouldn't normally speak to: it wasn't only student union leaders, but also employers of larger organizations and so on. Bryson continues to have an interest. He's the reason I appeared as a witness before the House of Commons Finance Committee. Just last week I met with Rodger Cuzner, a Liberal MP, who's taken an interest in the issue. I've had a number of meetings with provincial politicians to discuss the issue, private member's bills, amendments to the Canada Labour Code, and gathering statistics etc.

AL: It's heartening to see labour organizations such as Unifor and the Canadian Media Guild discussing unpaid internships. There's a lot of potential for organized labour in Canada to take up this issue and use it as a means to highlight to young people why unions are a necessity in the $21^{\text {st }}$ century.

EH: There are many more opportunities for collaboration with trade unions and student unions. For example, on the issue of academic internships, for those to have academic credit attached they usually need approval from a senate or faculty council. Members of both faculty and student unions (and sometimes staff unions as well) have votes. In unionized workplaces there might be other opportunities to support unpaid interns through bargaining and enforcing collective agreements.

CS: A group that is most aligned with the Intern Association is Generation Squeeze. They're from British Columbia. They have a mandate that's related to intergenerational equality. They have a deep understanding and interest in the intern issue. I see groups like this as the future and our strongest partner.

In Ontario and federally, what do you see as the most promising policy paths to change? For example, is addressing unpaid internships a matter of enforcing regulations that are already on the books? Updating regulations? Pressuring unions to regulate interns' conditions?

AL: For me, what's most important is meaningful law reform to address the conditions of precarious work, and the working conditions that young people are increasingly facing in the labour market. Part of that would be proactive enforcement programs and properly resourcing provincial ministries and departments that are carrying out labour regulation functions, giving them the adequate human and financial resources to carry out this mission. Labour ministries have been starved of resources over the past twenty to thirty years, which has stymied effective regulation.

What specific labour law reforms do you think are most pressing? 
CS: First, the law across Canada should be cohesive and clearly communicated. All internships must be paid unless the intern is receiving academic credit or a professional exemption applies. In Ontario, the Employment Standards Act should not include the "trainee" six-part test. Federally, the Canada Labour Code should include an exemption for students and ensure all non-student interns are paid. Second, all interns and students must be covered under health and safety laws. They are in some provinces; they're not in other provinces or federally. Third is enforcement: improve enforcement of the first two points, which goes back to Andrew's point about more funding for enforcement. Fourth, improve oversight for student internships and internships that are a part of professional training, which would include not just the ministries of labour but also ministries of education and training. Fifth, develop policy statements on volunteerism to distinguish the practice from unpaid labour.

JM: In terms of law reform, basically: ban unpaid internships outside of post-secondary programs; regulate and narrow the scope of unpaid internships through post-secondary programs, so that there are clear criteria and guidelines, and it's not just what exists now: complete exclusion from the Employment Standards Act for interns through post-secondary programs, regardless of what their placement looks like.

AL: Students need to have meaningful recourse within the context of academic internships. There's also the trend in some professional programs to require unpaid labour as a part of the licensing process: registered dieticians; now with law; nursing, to a degree; social work. I think this is an issue because these programs grant credentials, and people have to enter these programs to access the labour market. There are a lot of difficult questions: How do people survive when they're in these programs? How do they access financial resources?

We need to move towards a system based on co-op education, where students get paid when they're doing work. The University of Waterloo model is worthy of examination. We can also look at government-funded, paid internships. I think we need to make greater use of active labour market programs and devote greater governmental resources to paid training programs. We also need to look at apprenticeship programs. I don't think we need vast amounts of the youth population going into university, necessarily. There are other means to train and resource people with the appropriate levels of skills needed for our labour market and economy.

EH: Academic internships need to be much more narrowly defined in the Employment Standards Act, and there needs to be a mechanism for external oversight. Post-secondary education institutions have shown they're unwilling to exercise meaningful control internallywe only have to look to unpaid internships that have students cleaning rooms or serving breakfast in hotels to see this. l've also heard from students that some colleges are recruiting students to programs with mandatory co-op terms by telling them the placements are paid; after starting the program they find out most placements are unpaid. That false advertising is another problem.

Do you see any potential problems with organizing interns or analyzing the intern issue in isolation from other segments of the labour force? In other words, how does the plight of interns and the activism of intern groups relate to precarious employment more broadly? How does this issue intersect with race and citizenship, for example? Does intern activism address a privileged segment of the labour force?

AL: There's a lot of overlap between the issues that interns face and those that other historically marginalized groups face. It's all part of the puzzle of precarious work. We've created this "precariat" and young people are part of that. You also have the development of a large, low-waged service class. There are a lot of aligned issues, but there are differences. "Are interns in a privileged position?" Yes, I think that criticism can be made of some cases. But there's quite a bit of diversity in the types of interns that are out there, from older workers who are trying to retrain for a new career to women who are re-entering the workforce after 
devoting years to childcare [...] There can be recent immigrants in internships. This isn't just an issue related to young people. There are other groups that this impacts. I don't think there's an "ideal" version of the intern.

CS: We receive e-mails all the time from interns, and anecdotally, l'd say that fifty percent of the e-mails come from older workers, immigrants, and people of colour. I can think of several stories from young mothers re-entering the workforce, from immigrants to Canada who have been exploited in their internships, from people who feel they've been discriminated against in their internships, and then there's the gendered element, too, the sexual harassment. The people who email us are usually desperately looking for work experience and would of course prefer to be paid. Many feel that internships are the only way they can get the job they want.

JM: Even a paid internship is still precarious, temporary employment. In some cases, it works well for a summer student, who, for instance, does a four-month internship in the summer during their studies. In many other cases, interns are not students between semesters, and, even if they're paid, they're precariously employed, detached from any meaningful, long-term employment.

EH: It's a misconception that interns are all young and privileged. Even among young people many are funding internships through debt. Many new immigrants and women re-entering the workforce do unpaid work (although they may be more likely to be incorrectly called volunteers than interns). In certain industries, where many unpaid interns are very privileged, opening those opportunities to people who can't afford to work for free by ending unpaid internships is important. Unpaid internships shut people who can't work for free out of industries like journalism, politics, and fashion.

In the past few years, the intern issue has received a great deal of mainstream media attention. You've served as a public commentator, or media source, in the coverage. Why do you think the media has become interested in the issue in the first place? Why did the issue take off in mainstream media? And what has your experience as a source taught you about how the topic gets framed and the debate circumscribed by the media?

CS: The Intern Association started in June of 2012 and immediately started to attract interest. I had only been involved in the issue for about one month when I got an e-mail from a CBC producer to speak about the issue on The Lang and O'Leary Exchange. Why did that happen? I'm pretty sure that, with a name like Canadian Intern Association, those first reporters found us through Google. I remember feeling surprised: I came up with this idea to start an organization, and, two weeks later, CBC Radio wanted to interview me. I gained experience over time and my interview skills improved. I think a lot of the Canadian Intern Association's legitimacy has built from the media attention.

One thing I will say about the media stuff is that it's been 100 percent reactive. Before 2014 , I never reached out to a journalist to write about the issue, to say, "this is a good story." Every time, it was an e-mail or a phone call that I got from someone who was interested. Only in the past year I have called reporters that l've gotten to know to say, "You should write on this issue." 100 percent of the time that l've called a reporter to write on an issue, they have.

Do you think there are any limitations to the coverage or the debate in the media? Are there issues or perspectives that you haven't been able to get through?

CS: The limit is the individual stories. I'm able to talk to reporters about the law or the reforms and so on. But, all the time, they ask, "Can you put me in touch with someone to be my key person in the story?" The anecdotal story. I want to help them, but it's difficult. I reach out to interns to the extent that I have the time, and they never want to talk to media, understanda- 
bly. Jainna Patel is the best example because she's been so willing to talk to media. Also because she's a woman of colour, it's important that she's able to speak out about the issue (Patel received media attention in Ontario after she filed a complaint against Bell Mobility's Professional Management Program in 2013, claiming the internship was in fact menial work, not training, for which she should be paid). I often skirt the question about my own internships, because I would prefer to be a representative of the issue at large. I don't want to be an anecdote. I want to find more interns who are willing to talk about sexual harassment. It's something that so many young women have experienced in internships, and I've experienced it. It's hard to find people who want to talk to media about that, understandably. That part isn't getting enough attention.

What we need is funding to do a proper survey that's representative of the challenges with internships. But that would require a fair amount of money that we don't have. Hopefully, at some point, we could apply for a grant and do a large national survey to get information about sexual harassment in internships, about discrimination, about health and safety, all those different things.

\section{About the Participants}

Ella Henry

Ella Henry is co-chair of Students Against Unpaid Internship Scams. She has a BA in Sociology and Economics from St. Thomas University and a law degree from the University of Toronto.

\section{Andrew Langille}

Andrew Langille is a Toronto-based lawyer with a practice focused on employment, labour, and human rights law. He holds a Master of Laws from Osgoode Hall Law School. His graduate research focused on employment standards within the school to labour market transition. Currently, he acts as the General Counsel for the Canadian Intern Association. He is a frequent commentator in the media on labour market issues and blogs about youth employment issues at youthandwork.ca.

\section{Joshua Mandryk}

Josh Mandryk is a Toronto-based labour lawyer and advocate for interns' rights. He holds a Juris Doctor from the University of Toronto Faculty of Law and is called to the bar in the province of Ontario.

\section{Claire Seaborn}

Claire Seaborn holds a Juris Doctor from the University of Ottawa, Faculty of Law and a Bachelor of Arts in Political Science and Geography from the University of British Columbia. She is currently completing her Articles of Clerkship at Torkin Manes LLP in Toronto and was called to the Ontario bar in June 2015. As President of the Canadian Intern Association, Claire has appeared on the CBC's The Lang and O'Leary Exchange, The Business News Network, CTV News and Radio-Canada, and been quoted in the Globe and Mail, iPolitics, The Toronto Star, The Canadian Press, and Maclean's magazine. In the past year Claire has given submission to the House of Commons Finance Committee twice and was quoted in the 2015 federal budget. 